\title{
ALQUIMIA EXPERIMENTAL
}

Pedro Augusto F. Borges ${ }^{\mathrm{a}}$, Louise Vasconcelos Groener ${ }^{\mathrm{a}}$, Gabriel Pereira Gomes ${ }^{\mathrm{a}}$, Joanna P. Rodrigues ${ }^{\mathrm{a}}$, Geraldo Magela de Lima $^{a}$, Wagner N. Mussel ${ }^{a}$, Rodinei Augusti ${ }^{a}$ e Carlos A. L. Filgueiras*,a,

aDepartamento de Química, Instituto de Ciências Exatas, Universidade Federal de Minas Gerais, 31270-901 Belo Horizonte - MG, Brasil

Recebido em 04/03/2020; aceito em 17/06/2020; publicado na web em 06/08/2020

\begin{abstract}
EXPERIMENTAL ALCHEMY. Much is said and written regarding alchemy all across the world, in what could be called a renaissance of alchemical studies. However, relatively little is done in terms of actual alchemical laboratory work. The aim of the project described herein was to show how crucial the development of technical alchemical practice was along the centuries, in the discovery of an immense number of substances, processes and operations, which were of paramount importance in the establishment of modern chemistry. Alchemy is often derided in many circles. On the contrary, for two thousand years it constituted the basis of humankind's understanding of the material world and the changes undergone by compounds and materials. Here we present an experimental reconstitution of several alchemical discoveries of great importance, using old descriptions followed by modern characterizations. The results were often startling and demonstrated how ancient wisdom bore fruit in different ways, even in the absence of our present-day means of analysis.
\end{abstract}

Keywords: experimental alchemy; ancient chemical practice; alchemical processes.

\section{INTRODUÇÃO}

A alquimia foi por dois milênios o paradigma que norteou os estudos e a prática que buscavam compreender as relações, o comportamento e as transformações sofridas por tudo aquilo que constitui o mundo material. Ela foi cultivada sob diversas formas e vertentes, como a alquimia alexandrina, a chinesa, a hindu, a persa, a árabe e a ocidental, ou latina. A alquimia de que nos ocuparemos aqui deriva da vertente desenvolvida a partir de Alexandria, no antigo Egito, e das culturas islâmicas, culminando na alquimia ocidental. Nos estudos alquímicos houve desde tempos imemoriais duas abordagens diferentes que frequentemente se cruzavam. Uma delas dizia respeito a uma visão mais técnica, buscando obter resultados práticos, ao passo que a outra privilegiava aspectos místicos, ou esotéricos, em que se procurava relacionar o comportamento do mundo material com o mundo espiritual. Ambas as vertentes tiveram enorme papel no surgimento de várias futuras ciências. ${ }^{1,2}$ Basta lembrar aqui a importância da teoria alquímica das "virtudes" que os corpos exercem sobre os outros à distância. Essa crença teve grande influência sobre Isaac Newton, um assíduo praticante de alquimia esotérica, sobre a qual ele escreveu muito mais que sobre física ou matemática, embora sem publicar seus escritos, que só vieram à luz no século $\mathrm{XX}$. A teoria das virtudes se contrapunha à teoria dominante em meados do século XVII, pela qual o movimento planetário só se podia transmitir por contacto direto. ${ }^{3}$ Newton se opôs às ideias de Descartes, segundo as quais o movimento dos planetas era transmitido pelos vórtices de uma substância hipotética que permearia todo o universo, o "éter", em movimentação constante a partir da criação do universo por Deus. Newton contrapôs a essa doutrina sua ideia de ação à distância, de origem alquímica e oriunda do conceito de "virtudes" exercidas à distância pelos corpos uns sobre os outros, e fundamental na gênese da teoria da gravitação. Embora essa ideia inicial de ação à distância tenha sido eventualmente substituída pela de "campos" (campos gravitacionais inicialmente, depois também campos elétricos e magnéticos), a ideia de ação por contacto foi totalmente descartada, passando a simples curiosidade histórica. ${ }^{4}$

\footnotetext{
*e-mail: calfilgueiras@gmail.com
}

O estudo da alquimia mística ou esotérica tem, portanto, uma enorme importância para se entender como se desenvolveu a ciência moderna, e conta com muitos e notáveis estudiosos por todo o mundo. Nosso objetivo aqui, todavia, foi estudar as técnicas alquímicas, não só por meio de relatos antigos, mas sobretudo executando diversas operações de laboratório que recriaram várias reações e processos do passado, que muitas vezes nos surpreenderam e realçaram nossa admiração pelos alquimistas, suas técnicas e descobertas.

$\mathrm{O}$ estudo da alquimia na atualidade também tem uma função adicional, qual seja a de deitar por terra certos preconceitos arraigados que volta e meia se ouvem em vários meios, inclusive no meio acadêmico. Um desses preconceitos é o de que os alquimistas eram todos charlatães e embusteiros, que viviam de explorar a boa fé do resto da população. Esse preconceito sempre foi disseminado e tem grande antiguidade. Os próprios alquimistas, pelo secretismo que cultivavam em relação àquilo que faziam, contribuíram muito para essa desconfiança a seu respeito. Basta notar que na Divina Comédia, escrita em 1300, Dante Alighieri coloca os alquimistas no Inferno, no penúltimo círculo mais profundo, o oitavo, bem próximos ao fundo, onde reinava Lúcifer. Esse era para Dante o local adequado para aqueles falsificadores de ouro expiarem seus pecados. ${ }^{5}$ Ora, se havia charlatães entre os alquimistas, o mesmo sucede em qualquer outra atividade humana. Generalizar essa pecha para todos é um evidente exagero. O legado dos alquimistas, contudo, mostra que sua contribuição intelectual e material foi muito mais importante que quaisquer desvios éticos de alguns de seus praticantes, como nos propusemos a mostrar aqui. ${ }^{6} \mathrm{O}$ segundo preconceito que nos assola na atualidade é o desprezo votado por muitos a quase tudo da Idade Média, chamada por quem não a conhece de "Idade das Trevas". A expressão Idade Média foi cunhada de forma pejorativa pelos humanistas italianos do século XV para denominar os mil anos entre o fim do Império Romano e seu próprio tempo. Para eles, a civilização greco-romana havia sido o ápice do desenvolvimento humano em todos os aspectos, e tudo o que se seguiu, do século VI ao século XV, totalmente inferior. Esse é um julgamento injusto e preconceituoso contra um período que viu surgir a arquitetura gótica, com edifícios de 30 ou mais metros de altura e paredes de vidro, com vitrais magníficos, em que o peso da 
estrutura era engenhosamente levado para fora do edifício por meio dos arcobotantes, que se assentavam sobre pilares externos ao edifício, num virtuosismo de engenharia que depois se perdeu. Foi também um período de grande florescimento linguístico e literário, quando surgiram as línguas ocidentais, como a nossa própria. Atendo-nos apenas ao Ocidente, é importante salientar que a Idade Média foi a época em que se criaram as universidades europeias, antecessoras de nossas universidades modernas. Em contraste com o preconceito contra a Idade Média, basta acrescentar o enorme florescimento, nesse período, de muitas civilizações extra-europeias, ou de fora da civilização europeia ocidental, como a bizantina, a hindu, a persa, a chinesa, a árabe, a maia e outras mais, para citar apenas algumas, para as quais um desprezo a respeito do período da Idade Média não faria qualquer sentido.

O preconceito contra a Idade Média é tão arraigado que frequentemente se ouve falar dos horrores da Inquisição, instituição criada na Idade Média, como se seus piores aspectos tivessem ocorrido naquele período.

A Inquisição foi uma instituição iníqua e condenável por qualquer critério. Ela foi realmente fundada na Idade Média, mas é importante dizer que seu apogeu ocorreu na Renascença, sobretudo nos séculos XVI e XVII. Na Espanha ela foi introduzida em 1492 e em Portugal em 1536, portanto, em ambos os casos na Idade Moderna, em plena Renascença. ${ }^{7} \mathrm{O}$ curioso é que frequentemente se fala em Inquisição medieval, mas raramente em Inquisição renascentista. Não se pretende aqui denegrir os imensos avanços obtidos em todas as áreas pelo Renascimento ocidental, apenas chamar a atenção contra um preconceito injusto sobre o período anterior. O próprio deslumbramento inicial do Renascimento com os avanços da civilização greco-romana já havia sido superado em meados do século XVI, como muito bem o expressou o bardo maior da língua:

"Cesse tudo o que a Musa antiga canta

Que outro valor mais alto se alevanta."

Essa digressão em defesa da Idade Média faz sentido aqui quando se considera que o período mais longo de florescimento da alquimia foi durante aqueles anos. Além do mais, é completamente descabido um preconceito contra um determinado período histórico, qualquer que seja ele. Alega-se frequentemente que a Idade Média foi a época dos genocídios das cruzadas e das conquistas dos mongóis, por exemplo. É verdade, mas em termos de genocídios nenhuma época até agora pode comparar-se ao século XX.

O objetivo deste trabalho, entretanto, não foi o de escrever sobre a história da alquimia, mas sim de refazer no laboratório processos alquímicos de várias eras e lugares. $\mathrm{O}$ foco foi, acima de tudo, químico, mostrando como se pode fazer hoje, num laboratório moderno, as mesmas práticas antigas, e mostrar, a partir de métodos atuais de pesquisa, como o trabalho daqueles "antepassados" dos químicos modernos conseguiu desenvolver técnicas, equipamentos, reações, métodos e outros aspectos que levaram a um número impressionante de resultados que podem ser comprovados em nossos dias. Mesmo com um número limitado de processos experimentais, escolhidos de forma necessariamente aleatória, foi possível atingir o objetivo proposto. Agindo assim, foi nosso desejo desde o início mostrar o acerto de muito daquilo que se fez no passado, e como o desenvolvimento de tantos processos antigos pode ser repetido nos dias de hoje por estudantes de graduação, dando-lhes um sentido novo de maravilhar-se com o processo envolvido na descoberta científica. John Read, num livro antigo pleno de ideias filosóficas profundas, começa citando James Clerk Maxwell numa afirmação que ainda guarda muita pertinência: "James Clerk Maxwell, one of the greatest figures of physical science of the nineteenth century, once wrote: 'In science, it is when we take some interest in the great discoverers and their lives that it becomes endurable, and only when we begin to trace the development of ideas that it becomes fascinating'". ${ }^{9} \mathrm{O}$ objetivo de todo esse trabalho foi então primariamente químico, e não histórico.

$\mathrm{O}$ pesquisador americano Lawrence Principe, um dos principais propugnadores de trabalhos experimentais desta natureza, diz em seu livro The Secrets of Alchemy: "My goal ls to provide a reliable guide to the various secrets of alchemy. A comprehensive history of the subject not only would run to unreadable length but also would be premature...". ${ }^{10}$ Nosso objetivo aqui foi o mesmo, não o de escrever uma história da alquimia, mas de lançar mão dos conhecimentos antigos dos alquimistas e recriá-los num laboratório moderno, mostrando sua validação à luz da química atual. Este foi um projeto desenvolvido por quatro estudantes de iniciação científica, com a colaboração de alguns professores em determinados campos de pesquisa química (nenhum dos quais historiador da química), com o objetivo de desmistificar muitos dos mitos que cercam a alquimia nos dias de hoje, e mostrar como, ao contrário de ser um campo de conhecimento eivado apenas de mistério e superstição, a alquimia teve muitos aspectos importantes como desvendadora das relações sobre a constituição e as transformações da matéria, que pavimentaram o caminho para o aparecimento da química como a entendemos. Reiteramos então que nosso intuito não foi fazer uma história da alquimia, muito ao contrário. Por esta razão, pormenores oriundos de pesquisa mais recente desta mesma história, por mais fascinantes que sejam, não foram considerados, uma vez que fogem ao objetivo central, que é químico.

\section{PREPARAÇÕES EXPERIMENTAIS REALIZADAS A PARTIR DE RELATOS DE ALQUIMISTAS DO SÉCULO III AO SÉCULO XVII}

Neste projeto escolheram-se vários processos ilustrativos das inúmeras realizações da alquimia. A amostragem é necessariamente limitada e arbitrária, mas foi escolhida para mostrar a variedade e riqueza das atividades a que se dedicaram os alquimistas, tanto no aproveitamento de substâncias naturais como em seu uso para realizar reações químicas e obter novas substâncias.

Foram executadas 10 preparações no laboratório, seguindo os relatos de diversos alquimistas de diferentes países e épocas, da antiguidade ao século XVII. Em praticamente todas as preparações foi necessário realizá-las mais de uma vez, a fim de estabelecer parâmetros que descrevessem o trabalho de uma forma inteligível e reprodutível, de acordo com aquilo a que um químico moderno está habituado. Nos relatos de processos antigos nem sempre há o rigor de uma descrição moderna, em termos das quantidades de material usado, rendimento das reações, tempo e temperatura, solventes, etc. Tudo isso teve que ser testado laboriosamente para que os diversos procedimentos tivessem êxito. Procurou-se trabalhar sempre da forma mais fiel possível aos métodos e procedimentos antigos, com as ressalvas feitas abaixo. Em alguns casos foram feitas adaptações dos métodos nas descrições antigas com o intuito de proceder às reações em escala e tempo menores. Algumas reações eram realizadas pelos antigos em vasilhame de barro, mas aqui se procurou usar preferentemente vidro, que também era muito usado pelos alquimistas, para se poder visualizar o andamento da reação. Contudo, as caracterizações dos produtos obtidos foram sempre levadas a cabo lançando mão de métodos modernos. Isto nos fez apreciar muito mais o trabalho daqueles químicos do passado, nossos antecessores remotos que, em condições precaríssimas em comparação conosco, lograram tantos sucessos e conseguiram desenvolver uma enorme gama de sínteses, processos e operações de laboratório, sem os quais teria sido impossível o surgimento da ciência química que conhecemos, a partir de finais do século XVI e ao longo do século XVII. 
O método mais importante usado por nós para a caracterização de sólidos foi a difração de raios $\mathrm{X}$ de pó. Os difratogramas obtidos estão sempre mostrados aqui, junto à descrição dos sólidos estudados por este método.

As medidas de difração de raios $\mathrm{X}$ de pó foram obtidas em equipamento Shimadzu ${ }^{\circledR}$ XRD-7000 a 40 kV, $30 \mathrm{~mA}$, tubo anodo de $\mathrm{Cu} K \alpha(\lambda=1.54056 \AA)$ equipado com óptica policapilar para medida em geometria paralela, acoplado a um monocromador de grafite, com giro da amostra de $30 \mathrm{rpm}$ para minimizar qualquer orientação preferencial existente. Os experimentos foram obtidos na faixa angular de $10-70$ graus $2 \theta$, com incrementos de 0,02 graus $2 \theta$ e constante de tempo de $2,4 \mathrm{~s}$ por incremento.

\section{PREPARAÇÕES EXPERIMENTAIS EFETIVAMENTE REALIZADAS EM LABORATÓRIO NESTE PROJETO}

Os alquimistas do passado tinham várias maneiras de proceder. Uma regra bastante seguida era a calcinação dos sólidos e a destilação dos líquidos. Apesar de o primeiro procedimento nos parecer à primeira vista um tanto drástico, ele levou à descoberta de vários compostos novos, como o ácido sulfúrico, aqui relatado.

As 10 preparações executadas cobrem uma boa variedade de tópicos. Não tivemos qualquer veleidade de sermos exaustivos, apenas de mostrar como os alquimistas dominavam vários assuntos, e que suas operações podem ser repetidas e ampliadas nos dias de hoje por quem se interessar. Os tópicos estudados aqui compreendem:

"Ouro" alquímico. A crença generalizada na possibilidade da transmutação elementar, que só foi obtida em reações nucleares no início do século XX, levou muitos alquimistas a realizar operações engenhosas, muitas delas de boa-fé, na busca da transmutação de um metal "básico" num metal "nobre". A receita seguida por nós vem de Alexandria, no Egito antigo, e foi divulgada por um grande químico do século XIX, Marcellin Berthelot. A semelhança visual do produto obtido com ouro é impressionante, como se verá nas fotos.

Etanol. A antiguidade conhecia várias bebidas fermentadas, sobretudo o vinho e a cerveja. As bebidas destiladas e o próprio etanol levaram mais tempo para serem obtidas, em parte pela dificuldade em condensar o etanol, bem mais volátil que a água. O processo repetido aqui vem do século XII.

Ácido sulfúrico. É muito frequente ouvir de estudantes de graduação a pergunta inteligente sobre qual é a origem do ácido sulfúrico, um composto tão comum em nossos laboratórios. Em razão de sua grande reatividade, ele praticamente não existe na Terra, exceto em situações excepcionais, como durante uma erupção vulcânica, mas mesmo nesse caso sua existência é fugaz, em virtude de sua reatividade. Sua síntese por um alquimista data do século VIII.

Ácido nítrico. O ácido nítrico, chamado antigamente água forte, é facilmente obtido tratando o nitro, ou salitre, com ácido sulfúrico. Esse foi o método desenvolvido no século XIII e usado aqui.

Ácido clorídrico. Dos três principais ácidos minerais fortes, o ácido clorídrico foi o último a ser obtido, no século XVI. Conheciase o gás muriático, ou cloreto de hidrogênio, mas levou tempo até se perceber a importância do produto gerado pela reação do gás cloreto de hidrogênio com água, que é o ácido muriático, ou clorídrico.

Pigmentos. O ser humano sempre usou pigmentos os mais diversos, desde a mais remota pré-história, como mostram as pinturas rupestres disseminadas por todos os continentes. Após séculos, ou mesmo milênios, de uso de pigmentos naturais, surgiram os pigmentos sintéticos, alguns de grande beleza. Muitos destes pigmentos sintéticos têm sido fabricados há mais de 4000 anos. Aqui se mostrará a preparação de dois deles, o verdete e o branco de chumbo.

Cosméticos. No Egito faraônico mulheres e homens usavam uma sombra negra para os olhos, de um material obtido pela trituração fina de um composto natural, a estibnita. Mostraremos aqui tanto a estibnita natural como seu sucedâneo sintético, facilmente preparável experimentalmente.

Medicamentos. A estibnita, ou sulfeto de antimônio, tanto a natural como a sintética, podem reagir com o ácido clorídrico dando o tricloreto de antimônio, chamado antigamente de manteiga de antimônio. Esta manteiga de antimônio teve grande voga na Europa no século XVII e foi muito usada no Brasil colonial como medicamento.

Régulo de antimônio. A obtenção de um metal na forma elementar (os chamados régulos) por meio de uma reação de redox distinta dos processos metalúrgicos usuais foi algo que teve grande importância no século XVII. Um grande entusiasta dessa química foi Isaac Newton. Aqui se repetiu o processo de Newton para a obtenção do régulo de antimônio, reagindo-se o sulfeto de antimônio já disponível com cobre elementar. O produto é o chamado régulo venéreo, uma vez que o cobre estava associado ao planeta Vênus.

\section{OURO ALQUÍMICO}

A crença na realidade da transmutação de um elemento em outro dominou todo o pensamento alquímico em várias culturas, da antiguidade ao século XVII. Foi no século XVIII que se estabeleceu definitivamente a impossibilidade da transmutação elementar em processos puramente químicos. Em seu Tratado Elementar de Química, de 1789, Lavoisier definiu elemento como a menor porção de matéria que não perde sua individualidade numa transformação química. Em suas próprias palavras, diz ele, preferindo a expressão "corpo simples" a elemento, já que o termo elemento tinha sido fortemente associado às doutrinas alquímicas dos quatro elementos, que Lavoisier combatia: "tudo o que podemos dizer é que tal substância é o termo atual a que chega a análise química, e que ela não pode mais subdividir-se no estado atual de nosso conhecimento." 11

Já no início do século XX, Ernest Rutherford (1871-1937) e Frederick Soddy (1877-1956) conseguiram obter a transmutação por fissão nuclear natural quando estudavam as "emanações" do tório. Soddy, o descobridor dos isótopos, sugeriu que o tório originava um gás inerte (radônio), isso é, transformava-se em outro elemento. No dia em que isto foi percebido, em outubro de 1901, Soddy teria dito: "Rutherford, isto é transmutação."12 Todavia, eles preferiram não usar esta palavra, cheia de tanto significado alquímico, em sua primeira publicação sobre o assunto. Eles conseguiram mostrar que a desintegração produzia átomos mais leves a partir de átomos pesados em consequência de emissão alfa. Tanto Rutherford como Soddy ganharam o Prêmio Nobel de Química, o primeiro em 1908 e o segundo em 1921. Rutherford e Soddy conseguiram assim realizar o velho sonho dos alquimistas, embora de forma completamente diferente e inusitada.

$\mathrm{O}$ processo aqui executado foi retirado de um antigo papiro egípcio, da cidade de Alexandria, datado provavelmente do século III, e redigido em grego. Ele é conhecido como papiro de Leiden, por pertencer às coleções do museu daquela cidade holandesa. $\mathrm{O}$ papiro de Leiden foi bastante estudado no século XIX pelo eminente químico francês Marcellin Berthelot (1827-1907), um grande estudioso da alquimia, em adição a seus trabalhos como químico orgânico e termoquímico.

Os egípcios antigos, sobretudo em Alexandria, conheciam várias operações de laboratório, como a calcinação dos sólidos, a destilação, a filtração, vários tipos de aquecimento brando ou intenso, como os banhos de areia, de água (também chamado de banho-maria, por uma lendária alquimista da Antiguidade, chamada às vezes de Maria Egipcíaca ou Maria Judia). As retortas, balões e frascos de todo tipo também tiveram sua origem entre os alquimistas alexandrinos. 
Técnicas assim permaneceram e sempre foram fundamentais para o progresso da ciência química.

As Figuras 1 e 2 apresentam desenhos de aparatos alquímicos divulgados no século XIX por Marcellin Berthelot. ${ }^{13}$

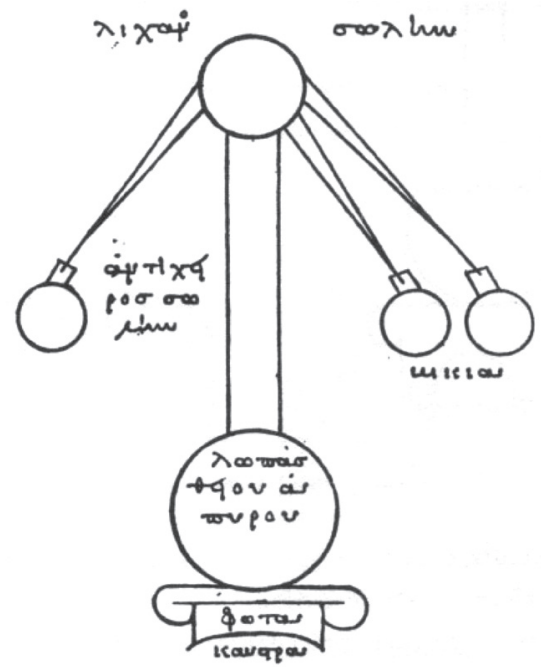

Figura 1. Alambique com três recipientes, no Manuscrito grego de São Marcos, conservado em Veneza (século XI) ${ }^{14}$

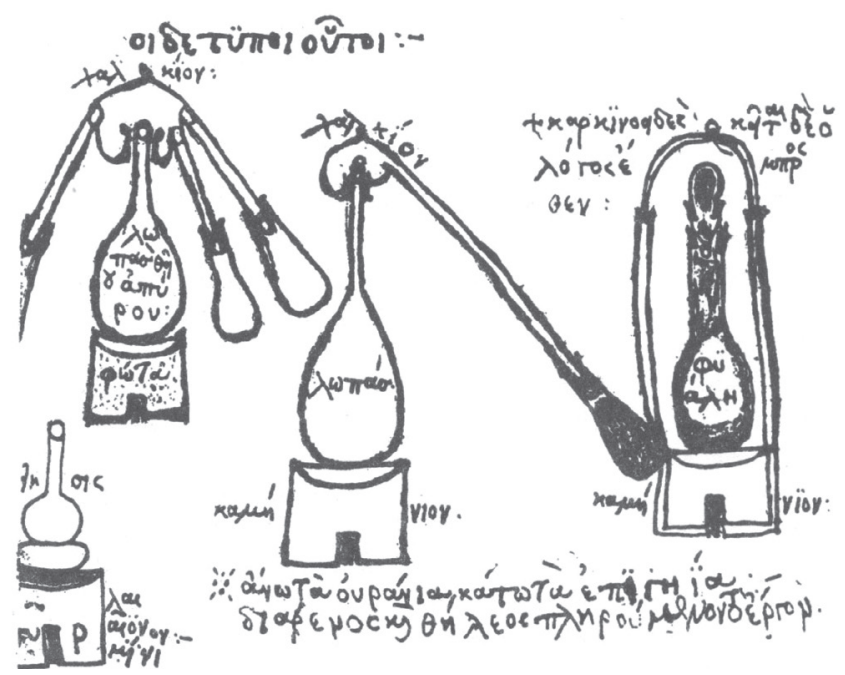

Figura 2. Alambique e vasos de digestão, no Manuscrito 2327 da Biblioteca Nacional de Paris, de $1478^{15}$

O processo de preparação do ouro alquímico consta do papiro de Leiden, oriundo de Alexandria ou, segundo alguns, de Tebas, e consiste na preparação de sulfeto estânico, $\mathrm{SnS}_{2}$, a partir de polissulfeto de cálcio e estanho metálico. O sulfeto estânico é dourado e também é conhecido como ouro mosaico, tendo levado muitos alquimistas, de boa-fé, a acreditar estarem a caminho de produzir ouro artificial. Portanto, a pecha de considerar os alquimistas charlatães não se sustenta.

O famoso Papiro X de Leiden, uma coletânea de receitas alquímicas, está conservado, como se disse, no museu daquela cidade holandesa. Esse papiro foi descoberto no Egito no século XIX e é uma compilação de receitas alquímicas bem mais antigas que o século III, época em que foi redigido. ${ }^{13,16} \mathrm{~A}$ receita da obtenção da água de enxofre, em grego theion hudor, cujo nome se atribui, às vezes, a um trocadilho com água divina, pode ser vista em várias transcrições. Berthelot chama a receita da água de enxofre de preparação 89, ao passo que no livro mais recente de Robert Halleux ela é denominada pelo número $87^{17}$. O texto é o mesmo em ambas as transcrições: "Invenção da água de enxofre. Um punhado de cal, e o mesmo de enxofre em pó fino; ponha-os num recipiente contendo vinagre forte, ou a urina de um menino impúbere; aqueça por baixo até que o líquido sobrenadante se pareça como sangue; decante-o adequadamente para separá-lo do depósito, e use." ${ }^{17}$ A lenta reação que se passa é a formação de polissulfetos de cálcio, como se pode mostrar na equação moderna:

$$
\begin{gathered}
\mathrm{Ca}(\mathrm{OH})_{2(\mathrm{~s})}+\left(\mathrm{H}_{2} \mathrm{~N}\right)_{2} \mathrm{CO}_{(\mathrm{s})}+(\mathrm{x}+1) \mathrm{S}_{(\mathrm{s})}+\mathrm{H}_{2} \mathrm{O}_{(\mathrm{l})} \rightarrow \mathrm{Ca}\left(\mathrm{S}_{\mathrm{x}}\right) \mathrm{S}_{(\text {(sol) }} \\
(\mathrm{x}=2,4,5)+\text { produtos secundários. }^{18}
\end{gathered}
$$

A reação é levada a cabo por aquecimento intenso por cerca de 40 minutos a uma hora, resultando numa solução vermelha.

Berthelot acrescenta que a urina de uma criança era usada pelos antigos em muitas receitas. Ela agia provavelmente como fonte de fosfatos alcalinos e amônia, resultante da decomposição da ureia. Berthelot também nota que não há razão para que a urina seja de uma criança, e que em receitas posteriores não mais havia esta menção ao tipo de urina a usar. ${ }^{19} \mathrm{Em}$ nossos experimentos constatou-se que a reação se passa melhor sem usar ácido acético (vinagre), e a urina foi substituída por ureia.

O produto da reação foi filtrado para eliminar o excesso de cal e enxofre, e a solução vermelha de polissulfeto de cálcio foi aplicada sobre uma amostra de estanho metálico à temperatura ambiente, resultando na cor dourada que se vê nas fotos apresentadas aqui. A reação que ocorre na superfície do estanho é a formação do sulfeto estânico, também conhecido como ouro mosaico:

$\mathrm{xSn}_{(\mathrm{s})}+2 \mathrm{Ca}\left(\mathrm{S}_{\mathrm{x}}\right) \mathrm{S}_{(\mathrm{sol})}+4 \mathrm{H}_{2} \mathrm{O}_{(\mathrm{l})} \rightarrow \mathrm{xSnS}_{2(\mathrm{~s})}+2 \mathrm{Ca}(\mathrm{OH})_{2(\mathrm{~s})}+2 \mathrm{H}_{2} \mathrm{~S}_{(\mathrm{g})}$,

em que $\mathrm{x}$ pode ser variável. ${ }^{20}$

O alquimista árabe al-Razi, dos séculos IX-X, conhecido no Ocidente latino como Rhazes, também deu uma receita para preparar o polissulfeto de cálcio parecida com aquela do papiro de Leiden:

"Tome duas partes de cal que não tenha sido extinta, e uma parte de enxofre amarelo, e digira isto com quatro vezes (em peso) de água pura até que fique vermelho. Filtre e repita o processo até ficar vermelho. Então colete toda a água e ferva-a até que ela se reduza à metade, e use-a." ${ }^{21}$

A Figura 3 mostra fotos de amostras de estanho metálico tratadas com o polissulfeto de cálcio obtido, mostrando o douramento da superfície metálica pela formação de sulfeto estânico.

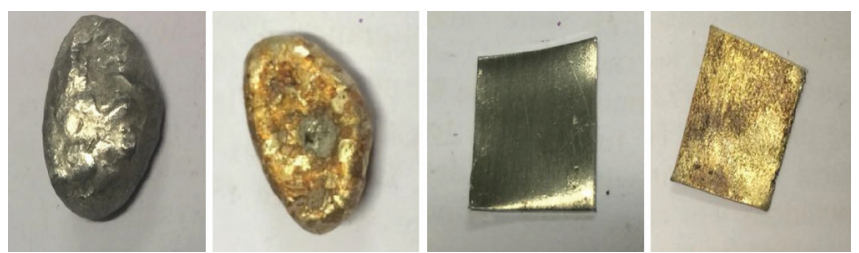

Figura 3. Amostras de estanho antes e depois do tratamento com polissulfeto de cálcio

A Figura 4 contém o difratograma de raios $\mathrm{X}$ obtido para uma amostra de estanho tratada com polissulfeto de cálcio, contendo o "ouro" alquímico, isso é, o sulfeto estânico. Aqui se mostra, portanto, uma caracterização inequívoca da formação de $\mathrm{SnS}_{2}$.

\section{ETANOL}

Desde a antiguidade se conheciam bebidas fermentadas, mas foi 


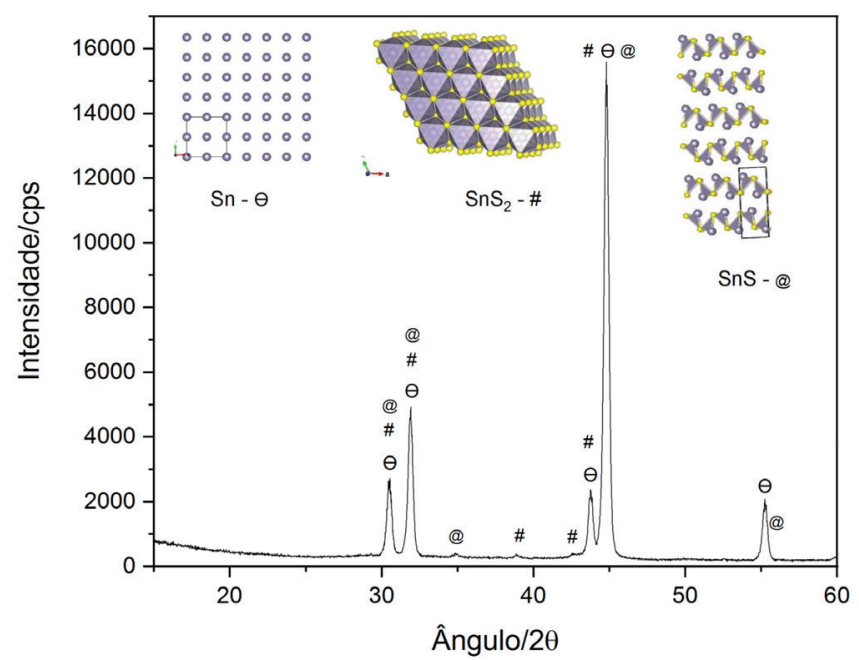

Figura 4. Difratograma em que se evidencia que a amostra é constituída de três fases distintas: a primeira de estanho metálico, mostrada no difratograma pelo símbolo $\theta$; a segunda e a terceira são, respectivamente, correspondentes às espécies SnS (símbolo: @) e SnS 2 (símbolo: \#), ambas presentes na superficie do metal

a partir da destilação do vinho que se obteve pela primeira vez uma água que ardia, a água ardente. Possivelmente o isolamento tardio do etanol deva ser creditado em parte à dificuldade dos alquimistas em conseguir condensar o álcool, bem mais volátil que a água. Os alquimistas consideravam a água e o fogo inimigos. Aquela extinguia esse, e o fogo fazia a água ficar tão irada que ela se transformava em "ar" (vapor). Ao destilar o vinho, os alquimistas da região de Salerno, no sul da Itália, obtiveram, com surpresa, uma "água" com características inusitadas. Essa água era agora "amiga" do fogo. Não só isso, mas ela ardia, deitando chamas, o que lhe valeu o nome de "aqua ardens", ou "água ardente". Este líquido também ficou conhecido como "aqua vitae", ou "água da vida". O processo de sua obtenção foi descrito por Magister Salernus (morto logo depois de 1167), que assim o descreveu em seu compêndio de medicina:

"Coloque numa cucúrbita uma libra de vinho branco ou tinto, uma libra de sal em pó, quatro onças de enxofre, quatro onças de tártaro de vinho (nome moderno: hidrogenotartarato de potássio). Colete o líquido destilado. Um pano saturado com este líquido manterá uma chama sem sofrer dano. $O$ algodão tem o mesmo efeito sem perda de matéria." 22

Assim se descobriram as bebidas destiladas e o etanol. No trabalho aqui realizado repetiu-se o processo, usando-se para isso uma retorta de vidro feita especialmente para nós pelo hialotécnico da UFMG, Wladmir Teodoro da Silva. Nela se destilou o conteúdo de uma garrafa de $750 \mathrm{~mL}$ de vinho tinto, como mostra uma das fotos abaixo. A água ardente obtida deu a bela chama azul do etanol em combustão, como se ilustra aqui (Figura 5). O forte cheiro característico do etanol e a chama produzida em sua combustão foram aqui considerados indícios suficientes de sua obtenção.

Um experimento como esta obtenção do etanol a partir do vinho é hoje tão corriqueiro e simples que corre o risco de ser desprezado como algo por demais elementar e banal. Contudo, é perigoso julgar o passado com os olhos do presente. A descoberta do etanol há mais de oito séculos constituiu um marco importante no progresso do conhecimento dos materiais e sua transformação, além do fato de que a nova substância veio a ter larga aplicação em inúmeras áreas de atividade humana.

\section{ÁCIDO SULFÚRICO}

Uma pergunta frequente é: como foi descoberto o ácido sulfúrico, uma substância tão reativa, que não existe livre na natureza? O ácido sulfúrico pode ser produzido em erupções vulcânicas ou em outras situações excepcionais, mas não é ordinariamente encontrado. Todavia, ele foi o primeiro dos três ácidos minerais mais importantes a ser descoberto. Essa descoberta se deu ainda na Alta Idade Média, a partir da calcinação do mineral vitríolo verde, ou sulfato de ferro heptaidratado. ${ }^{23}$ Ele foi obtido por bastante tempo dessa maneira, como mostra muito da literatura subsequente, até o século XVII. ${ }^{24}$ A calcinação do vitríolo verde possivelmente já poderia ser conhecida desde a Antiguidade, mas a recolha dos gases produzidos só começou a ser feita na Idade Média, pelos alquimistas islâmicos. Tradicionalmente se atribui a descoberta do ácido sulfúrico ao célebre alquimista árabe ou persa dos séculos VIII-IX Jabir ibn Hayyan, conhecido tradicionalmente no Ocidente medieval pela forma latinizada de seu nome, Geber. ${ }^{25}$ Embora as receitas originais não sejam precisas, todavia percebe-se uma distante influência dos alquimistas alexandrinos sobre os árabes. Em nosso laboratório efetuamos a calcinação do vitríolo de ferro, ou sulfato ferroso heptaidratado, que se apresenta como belos cristais verdes. De acordo com os alquimistas, a ação do fogo podia liberar o "espírito" volátil contido nos cristais. A calcinação executada por nós foi realizada a $750{ }^{\circ} \mathrm{C}$, e a reação química que ocorre, em linguagem moderna, pode ser escrita como:

$$
2 \mathrm{FeSO}_{4} \cdot 7 \mathrm{H}_{2} \mathrm{O}_{(\mathrm{s})} \rightarrow \mathrm{Fe}_{2} \mathrm{O}_{3(\mathrm{~s})}+\mathrm{SO}_{2(\mathrm{~g})}+\mathrm{SO}_{3(\mathrm{~g})}+7 \mathrm{H}_{2} \mathrm{O}_{(\mathrm{g})}
$$

No método original, a reação era conduzida em vasilhames de barro mantidos sobre um fogo intenso, possivelmente com o auxílio de foles. No nosso caso, a amostra de sulfato de ferro foi colocada em navetas de porcelana dentro de um tubo de quartzo aquecido num forno e os gases produzidos foram arrastados com argônio. Isso permitiu o uso de menores quantidades de material e rapidez no
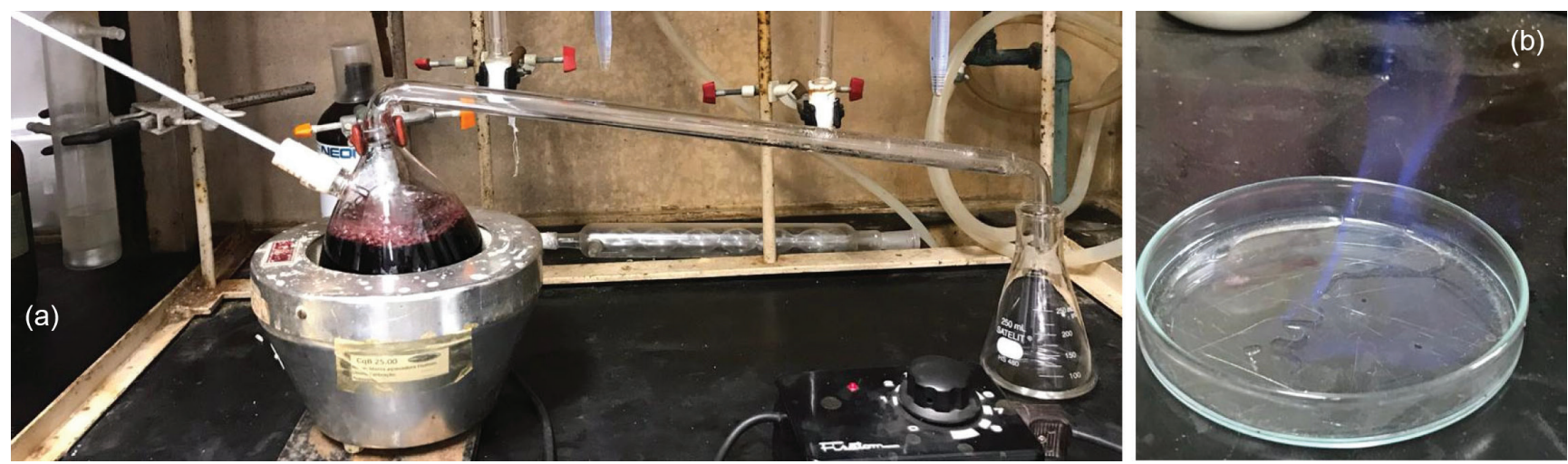

Figura 5. a) Vinho tinto sendo destilado numa retorta de vidro para produzir a água ardente; b) combustão do etanol destilado 
processo, que é essencialmente o mesmo dos alquimistas. Os materiais e o sistema usado estão mostrados na Figura 6.
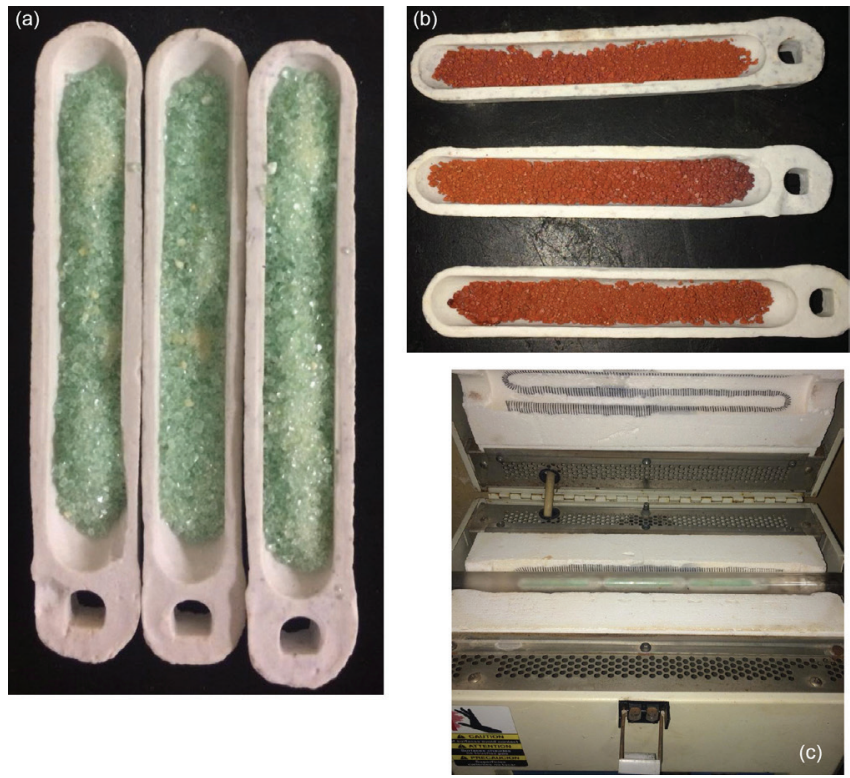

Figura 6. a) Navetas de porcelana com o sulfato ferroso antes da decomposição térmica; b) o resíduo de óxido formado ao final; c) forno usado no processo, a $750{ }^{\circ} \mathrm{C}$, e o tubo de quartzo com as navetas contendo o sulfato ferroso

Os produtos descritos foram caracterizados, confirmando as reações realizadas. $\mathrm{O} \mathrm{SO}_{3}$ reage com a água dando o ácido sulfúrico. Uma outra possibilidade é também a formação como produto secundário do ácido fraco $\mathrm{H}_{2} \mathrm{SO}_{3}$ a partir do $\mathrm{SO}_{2}$. O resíduo da reação é um pó avermelhado de óxido de ferro (III). A água destilada em que os gases foram absorvidos passou do $\mathrm{pH}$ 5,4 antes da reação para 2,2 após a mesma, indicando a formação de um ácido forte, em baixa concentração, como se determinou na titulação descrita abaixo. Foi inicialmente feita uma caracterização qualitativa da solução com cloreto de bário, que resultou no esperado precipitado branco de sulfato de bário, embora seja possível que tenha sido também produzido algum sulfito de bário, a partir de $\mathrm{SO}_{2}$ com água e posterior precipitação com cloreto de bário. A reação do ácido sulfúrico com o cloreto de bário é dada por:

$$
\mathrm{H}_{2} \mathrm{SO}_{4(\mathrm{sol})}+\mathrm{BaCl}_{2 \text { (sol) }} \rightarrow \mathrm{BaSO}_{4(\mathrm{~s})}+2 \mathrm{HCl}_{(\text {sol })}
$$

$30 \mathrm{~mL}$ da solução de ácido sulfúrico diluído obtida foram titulados com $\mathrm{NaOH} 0,1 \mathrm{~mol} \mathrm{~L}^{-1}$, gastando-se 1,7 mL dessa solução. Isso resultou numa concentração molar do ácido de $5,7 \times 10^{-3} \mathrm{~mol} \mathrm{~L}^{-1}$.

\section{ÁCIDO NÍTRICO}

A literatura antiga registra vários processos para a obtenção do ácido nítrico, chamado aqua fortis em latim, ou acqua acuta, em italiano. Esse último nome se encontra na obra de Vanuccio Biringuccio (1480-1538/9), um alquimista da cidade toscana de Siena. Ao longo da vida ele esteve ao serviço de vários senhores, terminando a vida como diretor do arsenal papal. Sua obra impressa mais importante é a Pirotechnia, em 10 livros, ou capítulos, publicada em $1540 .{ }^{26} \mathrm{O}$ ácido nítrico era importante para Biringuccio na análise e separação de ouro e prata. Ele descreve a preparação do ácido nítrico a partir da calcinação de dois minerais naturais, o salitre (nitrato de potássio ou, às vezes, também nitrato de sódio) e o alume (sulfato de alumínio e potássio dodecaidratado, $\mathrm{KAl}\left(\mathrm{SO}_{4}\right)_{2} \cdot 12 \mathrm{H}_{2} \mathrm{O} .{ }^{26}$ Outros autores dão diferentes formas de preparar a água forte. O já mencionado alquimista Geber ensinara a prepará-la com a destilação de uma mistura de vitríolo (ácido sulfúrico) e os minerais salitre ou sal amoníaco (cloreto de amônio). ${ }^{27}$

Neste trabalho optou-se pela reação entre o nitrato de sódio e o ácido sulfúrico:

$$
2 \mathrm{NaNO}_{3(\mathrm{~s})}+\mathrm{H}_{2} \mathrm{SO}_{4(\text { sol })} \rightarrow 2 \mathrm{HNO}_{3(\text { (sol) }}+\mathrm{Na}_{2} \mathrm{SO}_{4(\text { (sol })}
$$

Adicionaram-se numa retorta 42,5 g de $\mathrm{NaNO}_{3}$ e $25 \mathrm{~mL}$ de $\mathrm{H}_{2} \mathrm{SO}_{4}$ concentrado. A mistura foi aquecida até $250{ }^{\circ} \mathrm{C}$ e observou-se uma mudança de cor pela formação do gás marrom-avermelhado $\mathrm{NO}_{2}$ Coletaram-se $22 \mathrm{~mL}$ de destilado, que indicava um $\mathrm{pH} 3 \mathrm{com}$ papel indicador. Esse líquido incolor reagiu com uma amostra de cobre metálico, dando uma solução azul de nitrato cúprico e desprendendo o gás $\mathrm{NO}_{2}$ avermelhado. Esta última reação é típica e característica do ácido nítrico:

$$
\mathrm{Cu}_{(\mathrm{s})}+4 \mathrm{HNO}_{3(\mathrm{sol})} \rightarrow \mathrm{Cu}\left(\mathrm{NO}_{3}\right)_{2(\mathrm{sol})}+2 \mathrm{NO}_{2(\mathrm{~g})}+2 \mathrm{H}_{2} \mathrm{O}_{(\mathrm{l})}
$$

\section{ÁCIDO CLORÍDRICO}

O ácido clorídrico era conhecido de vários autores medievais e renascentistas, como Giambattista della Porta (1535-4-1615), mas o primeiro a dar instruções precisas de sua preparação e a prepará-lo em grandes quantidades foi o alemão Andreas Libau, ou Libavius (1540-1616). Libavius está num ponto de conexão entre a antiga Alquimia e a Química nascente. Embora acreditasse na transmutação elementar, a descrição de seus processos de laboratório já o aproxima mais dos químicos. Seu livro-texto Alchemia, de 1597, gozou de grande fama. Todavia, é em Syntagma, de 1611-13, que ele deu instruções precisas para preparar em grande quantidade o que ele chamava spiritus salis (espírito de sal), para o que hoje chamamos cloreto de hidrogênio. Ele também preparou o tetracloreto de estanho anidro, chamado spiritus fumans Libavii, ou espírito fumante de Libávio. ${ }^{28}$ No século XVII o alemão Johann Rudolph Glauber (1604-1670) fez fortuna com o produto sólido da reação entre o ácido sulfúrico e o cloreto de sódio, que ele comercializava por toda a Europa como medicamento para problemas digestivos. Por essa razão, o sulfato de sódio é até hoje conhecido pelo nome de sal de Glauber. Esta foi a reação conduzida por nós no laboratório:

$$
\mathrm{H}_{2} \mathrm{SO}_{4(\text { sol })}+2 \mathrm{NaCl}_{(\mathrm{s})} \rightarrow \mathrm{Na}_{2} \mathrm{SO}_{4(\text { sol })}+2 \mathrm{HCl}_{(\mathrm{g})}
$$

O gás cloreto de hidrogênio reage com a água dando uma solução de ácido clorídrico, com grande evolução de calor.

Na reação levada a cabo aqui foram misturados lentamente $50 \mathrm{~mL}$ de $\mathrm{H}_{2} \mathrm{SO}_{4}$ e $20 \mathrm{~g}$ de $\mathrm{NaCl}$ em um Kitassato conectado a um béquer com $50 \mathrm{~mL}$ de água destilada. Deu-se um leve aquecimento inicial ao Kitasato contendo a solução, que em seguida passou a reagir vigorosamente, sem necessidade de qualquer aquecimento adicional. Houve grande desprendimento do gás cloreto de hidrogênio, que foi coletado no béquer com água. Em 7 minutos a temperatura no béquer variou de $28^{\circ} \mathrm{C}$ a $85^{\circ} \mathrm{C}$, evidenciando a reação do gás formado com a água, resultando no ácido clorídrico. Esse ácido foi titulado por $\mathrm{NaOH} 1 \mathrm{~mol} \mathrm{~L}^{-1}$, dando uma concentração de 4,88 $\mathrm{mol} \mathrm{L}^{-1}$ para o ácido produzido.

\section{PIGMENTOS}

O uso de pigmentos sempre fez parte das mais variadas culturas, desde a pré-história. Aqui foram preparados dois deles, usados durante séculos, o verdete (6) e o branco de chumbo (7). Sugere-se ao leitor interessado no assunto consultar a literatura. ${ }^{29}$ 


\section{Verdete}

$\mathrm{O}$ verdete, ou acetato de cobre, $\mathrm{Cu}\left(\mathrm{CH}_{3} \mathrm{COO}\right)_{2} \cdot \mathrm{H}_{2} \mathrm{O}$, é um belo pigmento, de cor variando do verde ao azul, e chamado ao longo do tempo por vários outros nomes, como azinhavre, cristais de Vênus ou verdigris, em inglês. Esse pigmento tem sido usado há muitos séculos, e é formado facilmente pela reação do cobre com o ácido acético. Embora o cobre puro não reaja com um ácido não-oxidante como o ácido acético, o metal exposto ao ar reveste-se facilmente de uma camada de óxido, que reage muito bem com vários ácidos, inclusive o acético. A mesma palavra azinhavre é usada para descrever pigmentos semelhantes, mas com variações químicas. ${ }^{30}$ Por essa razão, o termo verdete é frequentemente usado de forma vaga, correspondendo a mais de uma espécie química definida, ou a uma mistura de espécies parecidas. Um tacho de cobre deixado ao relento, em presença de umidade e gás carbônico, na ausência de ácido acético, forma uma camada de pigmento esverdeado, com a formulação $\mathrm{Cu}_{2} \mathrm{CO}_{3}(\mathrm{OH})_{2}$, que também é denominado azinhavre. Num ambiente marinho a formulação pode ser $\mathrm{Cu}_{2}(\mathrm{OH})_{3} \mathrm{Cl}^{31}{ }^{31} \mathrm{Um}$ exemplo notável de produção espontânea de verdete pode ser visto na bela cor da Estátua da Liberdade, em Nova Iorque, coberta de azinhavre esverdeado. A estátua foi confeccionada com placas de cobre em 1885, e embora fosse originalmente da cor avermelhada desse metal, com o tempo adquiriu a complexa pátina esverdeada que apresenta, em cuja formação interferiram também agentes ambientais, como o $\mathrm{SO}_{2}$ da atmosfera e o $\mathrm{NaCl}$ da água do mar.

Um autor antigo que frequentemente cita o verdete (viride aeris em latim, ou verde de cobre) é Georgius Agricola, em seu livro clássico de mineração e metalurgia de 1556, De Re Metallica. ${ }^{32}$

No método aqui usado, puseram-se num béquer $90 \mathrm{~mL}$ de ácido acético glacial, no qual se dissolveram $38 \mathrm{~g}$ de $\mathrm{NaCl}$. O sal serviu para aumentar a força iônica do meio e facilitar a reação. Nessa mistura colocou-se uma placa de cobre e deixou-se a mistura reagir por uma semana. Ao cabo desse tempo, havia sido formada sobre o cobre uma bela camada do pigmento verde-azulado, como mostra a foto da Figura 7. A massa de verdete obtida pesou 0,105 g. A reação também foi realizada na ausência de $\mathrm{NaCl}$, mas nesse caso o processo se deu bem mais lentamente.

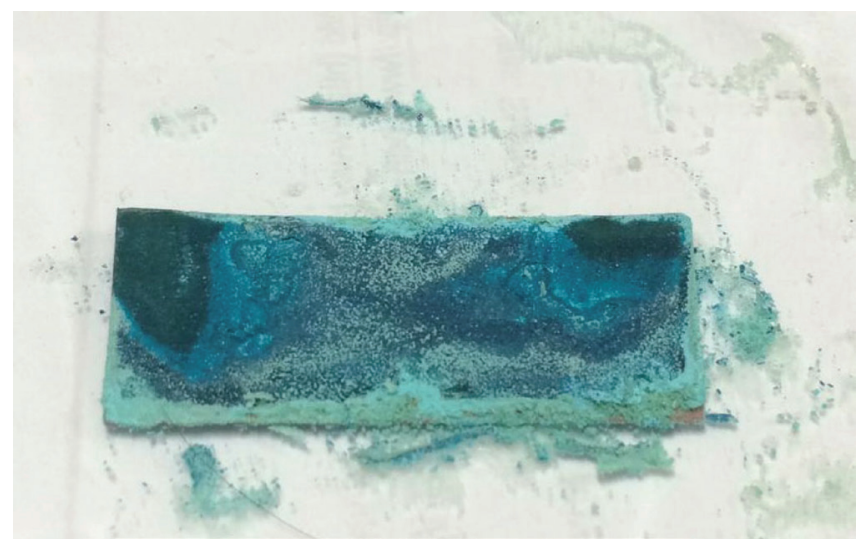

Figura 7. Formação do verdete, $\mathrm{Cu}\left(\mathrm{CH}_{3} \mathrm{COO}\right)_{2} \cdot \mathrm{H}_{2} \mathrm{O}$, numa placa de Petri

A Figura 8 mostra os difratogramas de raios $\mathrm{X}$ para o acetato de cobre comercial e para o produto sintetizado por nós, evidenciando uma perfeita identidade entre os dois.

\section{Branco de chumbo}

O branco de chumbo ou alvaiade é um pigmento branco usado desde a antiguidade. Ele foi durante séculos o pigmento branco mais importante após a invenção da pintura a óleo, no século XV. Sua

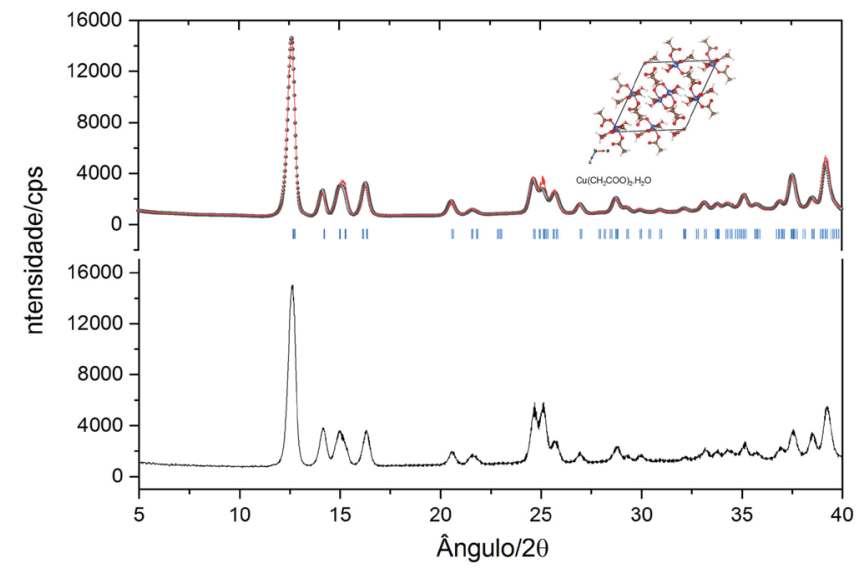

Figura 8. Difratogramas de raios $X$ do acetato de cobre comercial (acima) $e$ daquele sintetizado neste trabalho. Ambos correspondem à espécie $\mathrm{Cu}(\mathrm{CH}$ $\left.{ }_{3} \mathrm{COO}\right)_{2} . \mathrm{H}_{2} \mathrm{O}$, confirmando o resultado experimental

atração principal, comparado a outros pigmentos brancos, é atribuída a seu caráter "nacarado", que lhe dá um aspecto quase de pérola, muito apreciado pelos artistas. ${ }^{33}$ Todavia, seu uso foi proibido na maioria dos países, inclusive no Brasil, na segunda metade do século XX, em função de sua alta toxicidade, uma vez que o chumbo é um veneno cumulativo no organismo, levando, em casos extremos, à gravíssima doença denominada saturnismo. Hoje o pigmento branco mais usado é o dióxido de titânio.

O branco de chumbo é um sal básico, cuja fórmula é $2 \mathrm{PbCO}_{3} \cdot \mathrm{Pb}(\mathrm{OH})_{2}$, às vezes também escrita como $\mathrm{Pb}_{3}\left(\mathrm{CO}_{3}\right)_{2}(\mathrm{OH})_{2}$. Ele foi produzido ao longo do tempo por inúmeros processos, alguns bem curiosos. No século XVIII, por exemplo, uma das formas de obtê-lo consistia em expor tiras de chumbo aos vapores do vinagre e do esterco em fermentação. ${ }^{34}$

No caso presente, no lugar de esperar a lenta reação de oxidação do chumbo metálico ao ar, usou-se peridrol (peróxido de hidrogênio concentrado) no início da reação, para acelerar a oxidação inicial do metal a $\mathrm{Pb}^{2+}$. Aqueceu-se então uma mistura de 5,11 g de chumbo metálico com 5,0 mL de ácido acético e $8 \mathrm{~mL}$ de peridrol. Após um leve aquecimento, a mistura reagiu por 3 minutos, quando se adicionou excesso de carbonato de sódio e esperou-se que cessasse a efervescência. A mistura foi filtrada a vácuo e o sólido foi secado num dessecador. Esperava-se a produção do produto hidroxilado, mas tal não ocorreu, resultando apenas na formação do sal neutro, $\mathrm{PbCO}_{3}$. Esse resultado foi evidenciado pelo difratograma respectivo. As equações correspondentes estão mostradas abaixo:

$$
\begin{gathered}
\mathrm{Pb}+\mathrm{H}_{2} \mathrm{O}_{2} \rightarrow \mathrm{PbO}+\mathrm{H}_{2} \mathrm{O} \\
\mathrm{PbO}+\mathrm{H}_{2} \mathrm{O} \rightarrow \mathrm{Pb}(\mathrm{OH})_{2} \\
\mathrm{~Pb}(\mathrm{OH})_{2}+2 \mathrm{CH}_{3} \mathrm{COOH} \rightarrow \mathrm{Pb}\left(\mathrm{CH}_{3} \mathrm{COO}\right)_{2}+2 \mathrm{H}_{2} \mathrm{O} \\
\mathrm{Pb}\left(\mathrm{CH}_{3} \mathrm{COO}\right)_{2}+\mathrm{Na}_{2} \mathrm{CO}_{3} \rightarrow \mathrm{PbCO}_{3}+2 \mathrm{NaCH}_{3} \mathrm{COO}
\end{gathered}
$$

Para conseguir chegar ao sal básico, isso é, hidroxilado, decidiu-se por uma hidrólise lenta do produto na presença de uma solução saturada de carbonato de sódio. Modernamente isso poderia ser obtido mais facilmente usando-se $\mathrm{NaOH}$, mas o objetivo aqui era executar as reações da forma como eram conduzidas em séculos anteriores, quando não se dispunha de hidróxido de sódio como material alcalinizante, apenas de carbonato de sódio. Por isso, o carbonato neutro de chumbo foi agitado a $40{ }^{\circ} \mathrm{C}$ por três semanas em excesso de solução saturada de carbonato de sódio.

A equação respectiva pode ser escrita como:

$$
\mathrm{PbCO}_{3(\mathrm{~s})}+\mathrm{Na}_{2} \mathrm{CO}_{3(\mathrm{~s})}+2 \mathrm{H}_{2} \mathrm{O}_{(\mathrm{l})} \rightarrow \mathrm{Pb}(\mathrm{OH})_{2(\mathrm{~s})}+2 \mathrm{NaHCO}_{3(\text { sol })}
$$



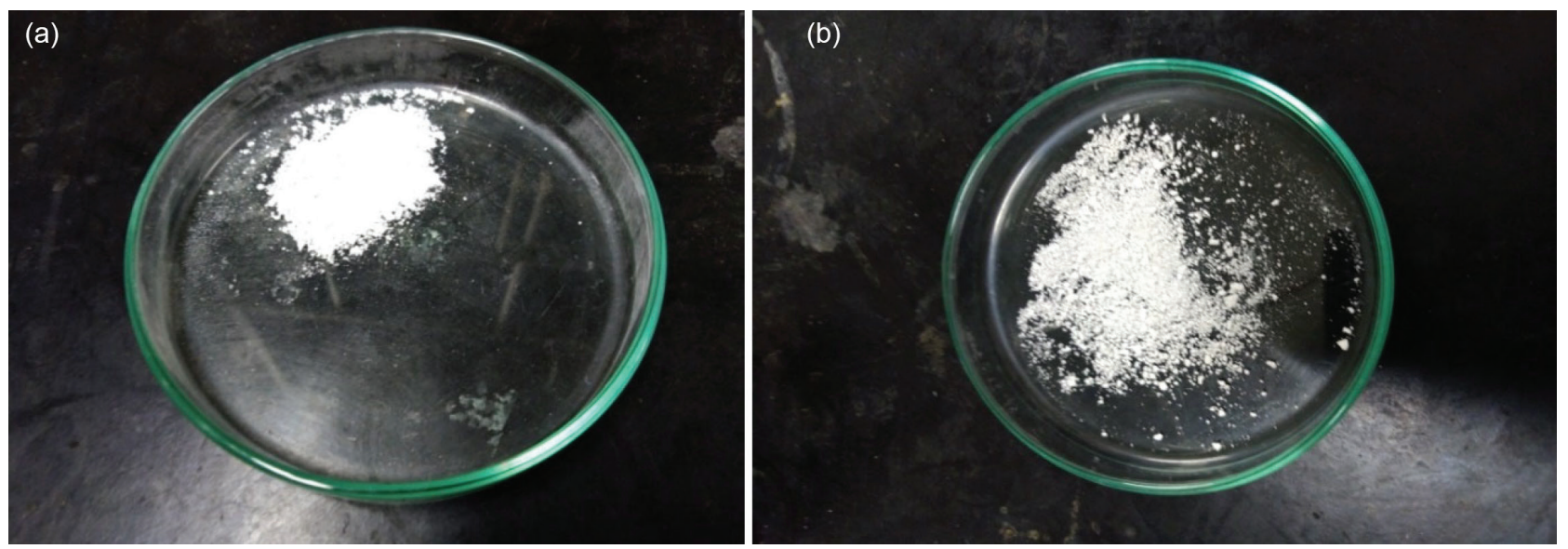

Figura 9. a) o sal obtido inicialmente, cujo difratograma corresponde ao carbonato neutro de chumbo, $\mathrm{PbCO}_{3}$; $b$ ) o produto após o processo de envelhecimento por hidrólise durante três semanas em solução saturada de $\mathrm{Na}_{2} \mathrm{CO}_{3}$

Embora o aspecto visual de ambos os sais seja praticamente idêntico (Figura 9), o material da Figura 9-b, de acordo com seu difratograma, é uma mistura de duas espécies hidroxiladas, $2 \mathrm{PbCO}_{3}$. $\mathrm{Pb}(\mathrm{OH})_{2}$ e $3 \mathrm{PbCO}_{3} \cdot \mathrm{Pb}(\mathrm{OH})_{2}$. $\mathrm{PbO}$, obtidas pelo tratamento prolongado com carbonato de sódio. É importante enfatizar que o carbonato neutro de chumbo foi completamente hidrolisado, não restando qualquer evidência cristalina de sua presença.

A Figura 10 apresenta na parte inferior o difratograma do carbonato neutro de chumbo e na parte superior os difratogramas dos dois produtos hidroxilados obtidos por hidrólise com a solução de carbonato de sódio.

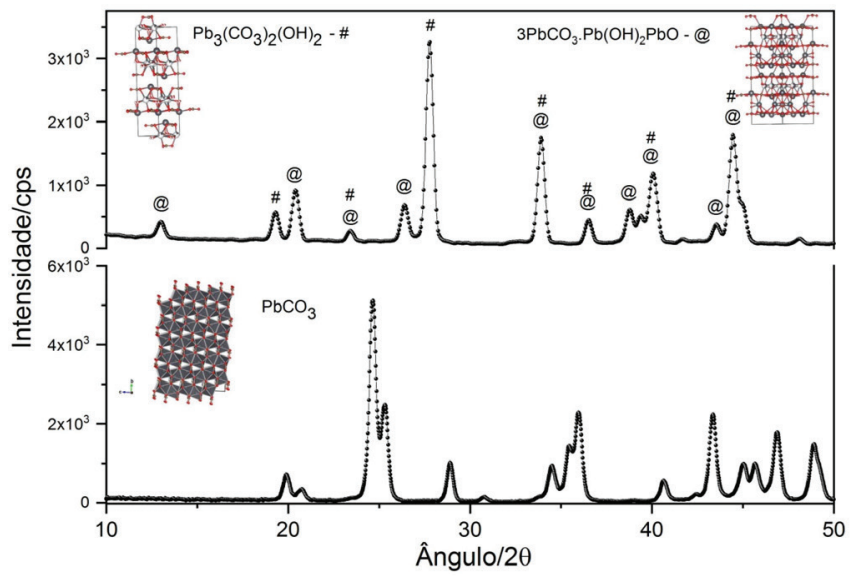

Figura 10. Difratogramas do carbonato neutro de chumbo (em baixo) e das espécies hidroxiladas produzidas por hidrólise lenta do carbonato de sódio

\section{COSMÉTICOS}

Os seres humanos usaram cosméticos desde a antiguidade mais remota. A Figura 11 é a foto de uma máscara mortuária egípcia do período ptolemaico, de 304 A.C., das coleções do Museu Nacional, lamentavelmente destruída no trágico incêndio do museu na noite de 2 de setembro de 2018. A foto mostra claramente na pintura facial o uso entre os egípcios de sombra negra para o entorno dos olhos. Embora outros compostos também tenham sido usados, o material principal usado no Egito faraônico era a estibnita, $\mathrm{Sb}_{2} \mathrm{~S}_{3}$, que forma um pó preto muito fino quando moída, e que adere à pele.

A Figura 12 apresenta amostras de estibnita natural e sintética.

Em virtude da dificuldade de obter quantidades apreciáveis de estibnita natural, optou-se aqui por preparar o $\mathrm{Sb}_{2} \mathrm{~S}_{3}$ sinteticamente, a partir da reação direta entre o antimônio elementar e o enxofre,

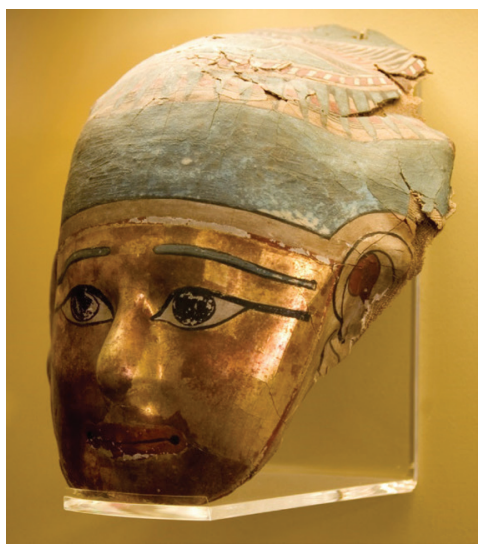

Figura 11. Máscara egípcia ptolemaica, de 304 A.C., em cartonagem revestida de folha de ouro e pintura, arrematada em leilão por D. Pedro I e doada ao Museu Imperial. Na pintura se vê claramente a sombra negra que se usava fazer com estibnita moída para delinear o contorno dos olhos

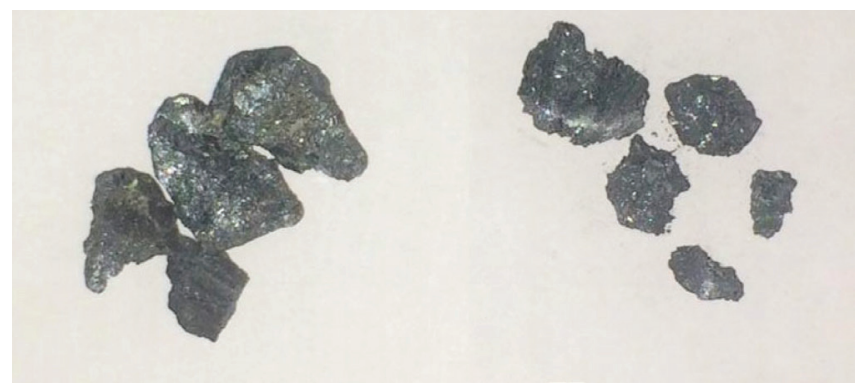

Figura 12. Estibnita natural, $\mathrm{Sb}_{2} \mathrm{~S}_{3}$, à esquerda, e aquela aqui sintetizada, à direita

ambos levados à forma de pó fino. A mistura foi posta num cadinho de porcelana coberto e aquecido vigorosamente sobre a chama de um bico de gás. $\mathrm{O}$ excesso de enxofre acaba formando $\mathrm{SO}_{2}$ e se desprende. A reação foi repetida várias vezes, adicionando-se mais enxofre e continuando o aquecimento, para garantir o consumo de todo o antimônio. A Figura 12 mostra o aspecto do produto sintético ao lado do material natural. Um pormenor linguístico curioso nesse aspecto é que os árabes passaram a denominar o produto usado pelos egípcios antigos por seu nome original, $k o h l$, precedido do artigo árabe $a l$. $\mathrm{O}$ produto preto kohl (palavra anterior à chegada dos árabes ao Egito) formava um pó muito fino e tênue, capaz de ser levado com facilidade pelo vento, e o termo veio a denominar também algo muito diáfano e volátil. Até hoje, no Egito, vendem-se aos turistas frascos de kohl, um 
pó preto extremamente fino e que adere à pele. Como o produto da destilação do vinho era o líquido mais volátil conhecido, ele passou então a ser chamado de $a l-k o h l$. Daí nós herdamos nas línguas ocidentais a palavra álcool. ${ }^{35}$ Essa associação entre o álcool e pós muito finos perdurou por muito tempo, como se pode constatar numa obra publicada originalmente em 1610, o Tyrocynium Chymicum, de Jean Béguin, um verdadeiro manual prático de farmácia, com inúmeras edições. Numa edição tardia de 1660 lê-se no texto latino que quando um pó se torna "impalpável, num sentido de sutilíssimo", ele passa a se chamar álcool. ${ }^{36}$

A preparação do $\mathrm{Sb}_{2} \mathrm{~S}_{3}$ pode ser escrita como:

$$
2 \mathrm{Sb}_{(\mathrm{s})}+3 \mathrm{~S}_{(\mathrm{s})} \rightarrow \mathrm{Sb}_{2} \mathrm{~S}_{3(\mathrm{~s})}
$$

A Figura 13 apresenta os difratogramas do antimônio elementar, acima, seguido dos difratogramas do $\mathrm{Sb}_{2} \mathrm{~S}_{3}$ natural, ou estibnita, e em terceiro lugar aquele do $\mathrm{Sb}_{2} \mathrm{~S}_{3}$ sintetizado por nós. O material sintético se mostrou idêntico ao natural.

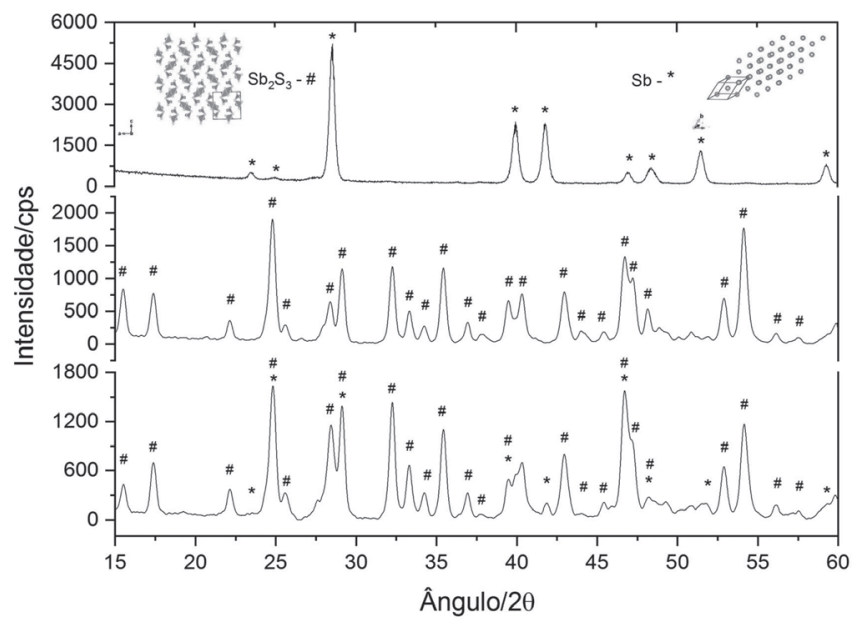

Figura 13. Difratogramas: acima, do antimônio metálico, do $\mathrm{Sb}_{2} \mathrm{~S}_{3}$ natural ou estibnita, no centro, e do $\mathrm{Sb}_{2} \mathrm{~S}_{3}$ sintetizado por nós, embaixo. As duas últimas figuras mostram claramente a identidade entre a estibnita natural e seu análogo sintético

\section{MEDICAMENTOS}

Muitos medicamentos químicos foram usados ao longo do tempo. No século XVI, o suíço Philippus Theophrastus Bombastus von Hohenheim (1493-1541) adicionou a seu nome o cognome Paracelsus, para dizer que ele estava muito além do famoso médico romano Celsus. Ele criou, contudo, uma nova modalidade médica que veio a ter muita voga nos séculos seguintes. Esta era a iatroquímica, ou química medicinal, que pregava que os medicamentos devem ser todos específicos para cada doença e que devem ser inorgânicos e sintéticos. Seu conceito de etiologia, ou que cada doença tem uma causa específica, foi importante numa época em que predominavam as triagas, misturas de dezenas de medicamentos usados para quase tudo, na esperança de que de alguma forma a cura pudesse ser alcançada. Embora o conceito de causa específica de cada doença tenha sido um avanço, os medicamentos sintéticos inorgânicos eram em sua maioria bastante tóxicos, como os sais de mercúrio, arsênio ou antimônio. $\mathrm{O}$ antimônio teve tamanha voga que um livro que circulou por muitos anos em diferentes edições e países foi a Carruagem Triunfal do Antimônio, em que se exaltavam as virtudes quase milagrosas dos sais desse elemento como medicamentos químicos. Esse livro é de autoria incerta, embora a tradição o ligue a um certo monge beneditino do século XV, Basílio Valentino. ${ }^{37}$

Aqui se usou o $\mathrm{Sb}_{2} \mathrm{~S}_{3}$ para preparar um composto muito utilizado pelos iatroquímicos, a manteiga de antimônio, nome antigo do que os químicos modernos denominam tricloreto de antimônio, $\mathrm{SbCl}_{3}$. A manteiga de antimônio foi largamente usada como remédio pelo menos até o final do século XVIII, inclusive no Brasil colonial, como recomenda o cirurgião português José Antonio Mendes, que atuou em Minas Gerais por cerca de vinte anos, na região do Tejuco e do Serro. Após retornar a Portugal, Mendes compôs e publicou um livro de medicina para a automedicação de quem vivesse longe de profissionais de saúde. Nesse livro, denominado Governo de Mineiros, publicado em Lisboa em 1770, ele recomenda o uso da manteiga de antimônio em sua lista de remédios que as pessoas deviam ter à mão em casa. ${ }^{38}$ Curiosamente, a palavra governo, no título do livro, tem a conotação antiga de tratamento. Mendes dá em seu livro uma série de aplicações em que a manteiga de antimônio era considerada um ótimo remédio: em chagas gálicas (feridas de origem venérea), tanto em homens como em mulheres, chagas da garganta ou do nariz, chagas cancerosas, cancros ulcerados, etc.

A reação de formação da manteiga de antimônio é simples, e transcorre com a evolução de sulfeto de hidrogênio, cujo forte cheiro é facilmente detectado. A reação pode ser descrita como

$$
\mathrm{Sb}_{2} \mathrm{~S}_{3(\mathrm{~s})}+6 \mathrm{HCl}_{(\text {sol })} \rightarrow 2 \mathrm{SbCl}_{3(\mathrm{sol})}+3 \mathrm{H}_{2} \mathrm{~S}_{(\mathrm{g})}
$$

A Figura 14 mostra o aspecto do tricloreto de antimônio logo após sua preparação, quando ele se apresenta como um pó de cor creme, após ser secado com aquecimento brando, e pouco depois de se expô-lo ao ar, quando ele absorve água da atmosfera e adquire $\mathrm{o}$ aspecto que veio a dar-lhe o nome de manteiga, pela semelhança

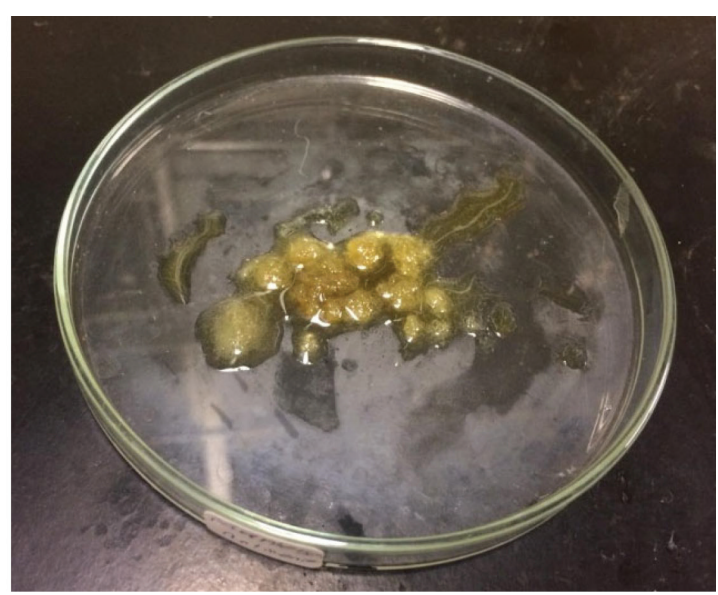

Figura 14. O tricloreto de antimônio recentemente preparado e secado em fogo brando, e depois de exposto ao ar por alguns minutos 


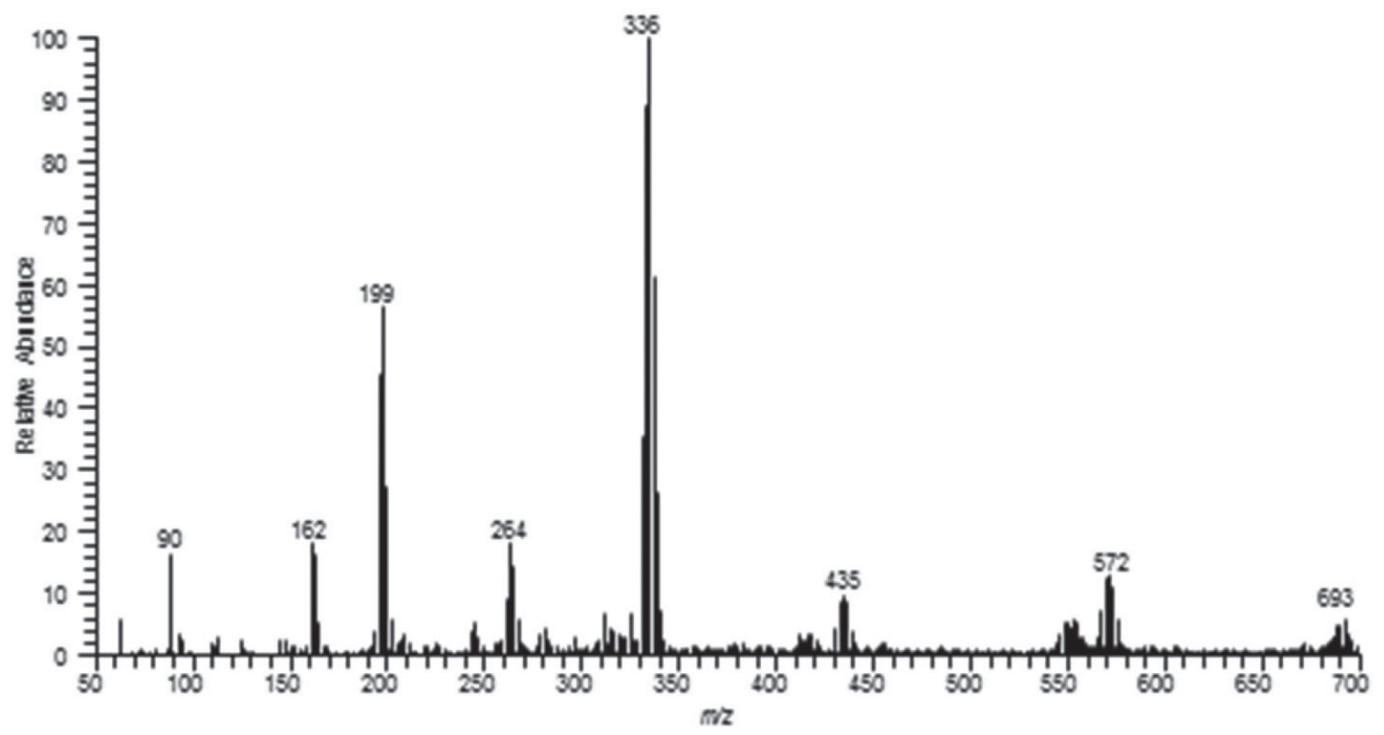

Figura 15. Espectro de massas do produto obtido da reação entre $\mathrm{Sb}_{2} \mathrm{~S}_{3}$ e $\mathrm{HCl}$, dissolvido em $\mathrm{MeOH}$ à razão de 1:10000

com ela. Depois de muito tempo, o material acaba por deliquescer e formar uma solução.

A caracterização do tricloreto de antimônio por difração de raios $\mathrm{X}$ tornou-se muito difícil por causa de seu caráter altamente higroscópico. Por essa razão, lançou-se mão da análise por espectrometria de massas, de acordo com a descrição a seguir.

A amostra recebida foi diluída em metanol numa proporção de 1:10000. A solução resultante foi inserida no espectrômetro de massas (modelo: LCQ Fleet, fabricante: Thermo Scientific, San Jose, CA) nas seguintes condições:

1) Fluxo da amostra: $10 \mathrm{~mL} / \mathrm{min}$;

2) Gás de dessolvatação: nitrogênio $\left(\mathrm{N}_{2}\right)$;

3) Temperatura do capilar: $275^{\circ} \mathrm{C}$

4) Modo de ionização: negativo

O espectro de massas obtido está mostrado na Figura 15.

No método utilizado, os cloretos são ordinariamente substituídos, de modo que as espécies detectadas neste experimento estão de acordo com substituições possíveis. A presença do sinal detectado com $\mathrm{m} / z$ 199 indica a presença da espécie $\left(\mathrm{H}_{3} \mathrm{CO}\right)_{2} \mathrm{SbO}^{-}$, provavelmente oriunda da reação do $\mathrm{SbCl}_{3}$ com metanol. Uma outra espécie, detectada no espectro de massas, refere-se àquela com $\mathrm{m} / \mathrm{z}$ 336. Para esta espécie, a seguinte estrutura dimérica foi proposta:

$$
\left[\mathrm{H}_{3} \mathrm{C}-\mathrm{O}-\mathrm{Sb}\left(\mathrm{O}_{2}\right) \mathrm{Sb}-\mathrm{O}-\mathrm{CH}_{3}\right]
$$

Tal estrutura é, provavelmente, formada nas condições da ionização electrospray.

\section{RÉGULO DE ANTIMÔNIO}

O nome régulo era dado aos metais que se obtinham na forma elementar, ou metálica, sobretudo o antimônio. Eles são famosos por sua associação com Isaac Newton, que os preparou em suas manipulações alquímicas. Existem diferentes razões alegadas para o uso do nome régulo para o produto da obtenção de um metal na forma elementar, sobretudo no caso do antimônio. Uma delas será dada a seguir. A palavra latina regulus, diminutivo de rex, isto é, reizinho, teria surgido porque o antimônio seria considerado um metal relacionado ao ouro, mas inferior a ele. Daí ser designado no diminutivo, ao passo que o ouro era o rei dos metais. O régulo de antimônio pode ser preparado a partir do $\mathrm{Sb}_{2} \mathrm{~S}_{3}$ e vários metais. Ele também é denominado régulo estrela, porque muitas vezes seu processo de cristalização faz com que ele adquira um formato estrelado. Em alta temperatura ocorre uma reação redox em que se produz o antimônio elementar e o sulfeto do metal que se usou. Os nomes alquímicos são sempre saborosos para designar a origem do régulo de antimônio, remetendo à associação entre os metais e os planetas. Assim, no nosso caso o régulo foi obtido com a utilização de cobre em pó, donde o nome de régulo de antimônio venéreo, por causa da associação do metal cobre com o planeta Vênus. Analogamente existem os régulos marcial $(\mathrm{Fe})$, saturnino $(\mathrm{Pb})$, joviano $(\mathrm{Sn})$ e lunar $(\mathrm{Ag}) .^{39}$

A reação executada consistiu em aquecer num forno a $600^{\circ} \mathrm{C}$ um cadinho de porcelana com uma mistura de $10 \mathrm{~g}$ de $\mathrm{Sb}_{2} \mathrm{~S}_{3}$ e $10 \mathrm{~g}$ de cobre em pó por uma hora. Adicionaram-se, então, 2,5 g de $\mathrm{KNO}_{3}$ como fundente e a mistura foi novamente aquecida à temperatura de $1000{ }^{\circ} \mathrm{C}$ pelo período de uma hora. Após esse tempo, o cadinho foi quebrado e obteve-se um disco do tamanho de uma moeda de um real (Figura 16). Esse disco foi cortado, mostrando o aspecto da Figura 17 , com uma parte central mais brilhante, constituída pelo régulo de antimônio, circundada por uma capa preta de sulfetos de cobre, como veio a mostrar a análise por difração de raios $\mathrm{X}$.

A reação redox simplificada em alta temperatura pode ser escrita:

$$
\mathrm{Sb}_{2} \mathrm{~S}_{3(\mathrm{~s})}+3 \mathrm{Cu}_{(\mathrm{s})} \rightarrow 2 \mathrm{Sb}_{(\mathrm{s})}+3 \mathrm{CuS}_{(\mathrm{s})}
$$

A Figura 18 mostra o difratograma do produto da reação entre o $\mathrm{Sb}_{2} \mathrm{~S}_{3}$ e o cobre elementar, evidenciando uma mistura complexa de

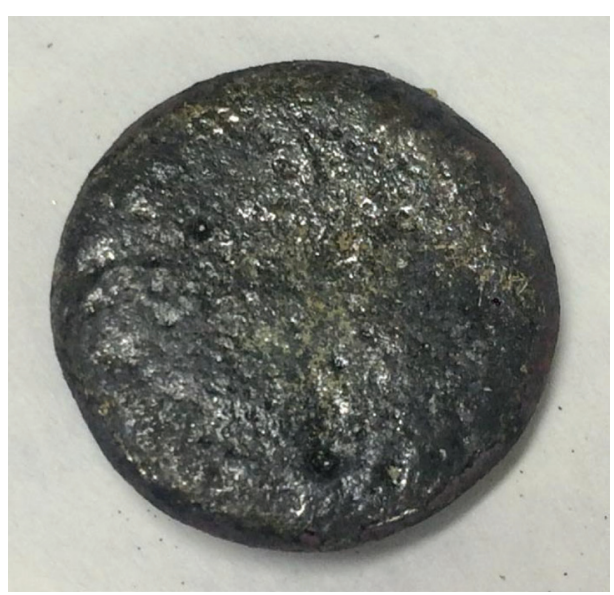

Figura 16. O disco obtido após a reação entre $\mathrm{Sb}_{2} \mathrm{~S}_{3}$ e cobre 


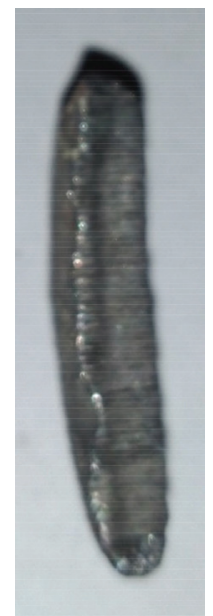

Figura 17. O disco cortado, mostrando a parte central, à direita da foto, formada pelo régulo de antimônio, e o envoltório de sulfeto de cobre, à esquerda

espécies. De fato o antimônio se reduziu do sulfeto ao estado metálico, o régulo, que aparece em duas formas cristalográficas distintas, dando as raias denominadas $\mathrm{Sb} 1 \mathrm{e} \mathrm{Sb} 2$. A raia mais intensa da figura mostra uma superposição de $\mathrm{Sb} 1$ com a espécie complexa $\mathrm{Cu}_{3} \mathrm{SbS}_{4}$. A longa manutenção da mistura de reação à alta temperatura de $1000^{\circ} \mathrm{C}$ pode ter causado migrações iônicas entre o excesso de $\mathrm{Sb}_{2} \mathrm{~S}_{3}$ e o CuS que se forma, resultando no sulfeto complexo observado acima, assim como na espécie intermetálica $\mathrm{Cu}_{6} \mathrm{Sb}_{4}$. É interessante voltar a destacar que a redução do antimônio ao régulo ocorreu, de fato, e veio acompanhada da oxidação do cobre, formando sulfetos complexos.

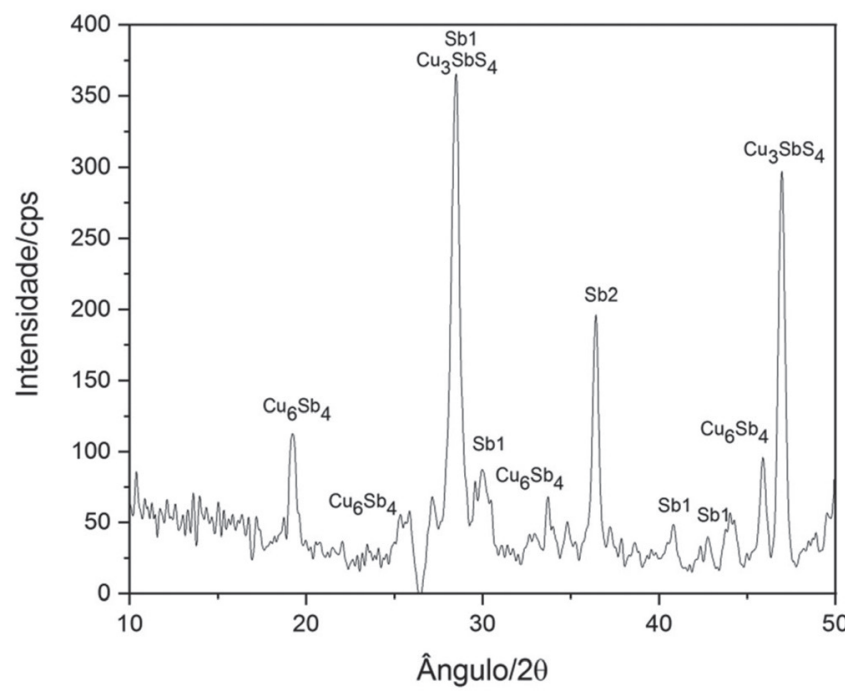

Figura 18. O difratograma da reação entre o $\mathrm{Sb}_{2} \mathrm{~S}_{3}$ e o cobre elementar mostrando uma mistura complexa de espécies

\section{CONCLUSÃO}

Este projeto mostrou que é possível recriar num laboratório atual uma série de experimentos levados a cabo no passado por alquimistas de diferentes épocas e lugares. A caracterização moderna dos produtos obtidos evidencia como esses antigos profissionais sabiam manipular substâncias e materiais com conhecimento e destreza, ao mesmo tempo em que dominavam uma grande variedade de operações e processos, usando equipamentos de sua invenção. A sua curiosidade a respeito da matéria e seu comportamento, aliada à engenhosidade como operaram, é notável e não deixa de nos surpreender nos dias de hoje. Com o tempo, os alquimistas vieram a acumular importantes conhecimentos sobre a natureza, as propriedades e as transformações da matéria, obtendo por vezes resultados inusitados e importantes. Nossa posição privilegiada em que podemos dispor de métodos contemporâneos para estudar os processos realizados só pode aumentar a admiração por esses químicos do passado. Uma ampliação da recriação dos trabalhos dos alquimistas em laboratórios modernos provavelmente poderá nos dar uma visão bem mais aprofundada a respeito das origens mais remotas de nossa ciência.

\section{REFERENCIAS E NOTAS}

1. Carvalho, R.; A Ciência Hermética, Relógio D’Água Editores: Lisboa, 1996, pp. 1-125.

2. Alfonso-Goldfarb, A. M.; Da Alquimia à Química, Nova Stella Editorial: São Paulo, 1987, pp. 1-279.

3. Dobbs, B. J. T.; The Foundations of Newton's Alchemy or, The Hunting of the Greene Lyon, Cambridge University Press: Cambridge, 1975, pp. 1-300.

4. Filgueiras, C. A. L.; Ciência e Cultura 1988, 40, 41.

5. Alighieri, D.; A Divina Comédia, Inferno, Canto XXIX, tradução de Cristiano Martins, Villa Rica Editoras Reunidas, Belo Horizonte, $6^{\mathrm{a}}$ ed., 1991, pp. 348-357.

6. Carvalho, op. cit., p. 55.

7. Marcocci, G.; Paiva, J. P.; História da Inquisição Portuguesa (15361821), $2^{\mathrm{a}}$ ed., A Esfera dos Livros, Lisboa, 2016, pp. 1-607.

8. Camões, L.; Os Lusíadas, Canto Primeiro, Estrofe III, Itatiaia-Edusp: Belo Horizonte, 1980, p. 30.

9. Read, J.; From Alchemy to Chemistry, Dover: New York, 1995 (1957), p. xiii.

10. Principe, L. M.; The Secrets of Alchemy, The University of Chicago Press, Chicago, 2013, p. 3.

11. Lavoisier, A. L.; Traité Élémentaire de Chimie, 1789, edição facsimilar, Librairie Scientifique et Technique Albert Blanchard, Paris, s.d., vol 1, p. 194.

12. Keas, M. N. In Nobel Laureates in Chemistry 1901-1992; James, L. K., ed.; American Chemical Society e Chemical Heritage Foundation, 1993, p. 53.

13. Berthelot, M.; Introduction à l'Étude de la Chimie des Anciens et du Moyen Âge, Georges Steinheil, Éditeur: Paris, 1889, pp. 1- 330.

14. Idem, ibid., p. 139.

15. Idem, ibid., p. 161

16. Leicester, H. M.; The Historical Background of Chemistry, Dover: New York, 1971, p. 38.

17. Halleux, R.; Les alchimistes Grecs, Texte Établi et Traduit para Robert Halleux, Société d'Édition Les Belles Lettres: Paris, 1981, p. 104.

18. Partington, J. R.; A Text-Book of Inorganic Chemistry, MacMillan: London, 1950, p. 758.

19. Berthelot, M.; op. cit., pp. 46-47.

20. Ref. 18 , p. 833.1

21. Ref. 16, p. 68.

22. von Lippman, E. O.; Chemiker Zeitung 1917, 884; von Lippman, E. O.; Chemiker Zeitung 1920, 625, apud Stillman, J. M.; The Story of Alchemy and Early Chemistry, Dover: New York, 1960, p. 190.

23. Lowry, T. M.; Historical Introduction to Chemistry, Macmillan: London, 1936, p. 13

24. Glaser, C.; Traité de la Chymie, enseignant par une brieve \& facile méthode toutes les plus nécessaires préparations, Paris, MDCLXVIII, p. 347, Gutenberg Reprints, Paris, 1980.

25. Lowry, T. M.; Idem, ibid.

26. Partington, J. R.; A History of Chemistry, vol. 2, 1961, Reprint Edition, Marino Publishing: New York, pp. 32-37.

27. Ref. 16, p. 77.

28. Ref. 26, p. 99. 
29. Friedstein, H. G.; J. Chem. Educ. 1981, 58, 291. O mesmo número da revista contém ainda vários outros artigos relacionados ao tema.

30. Uvarov, E. B.; Chapman, D. R.; Isaacs, A.; The Penguin Dictionary of Science, $5^{\text {th }}$ ed., Penguin Books: Harmondsworth, 1979, p. 452.

31. https://en.wikipedia.org/wiki/Verdigris, acessado em julho 2020.

32. Agricola, G.; De Re Metallica (1556), translated by Herbert Clark Hoover and Lou Henry Hoover, Dover: New York, 1950, livro X, pp. 439-90.

33. Corbeil, M.-C.; Sirois, P. J.; A Note on a Modern Lead White, Also Known as 'Synthetic Plumbonacrite', Studies in Conservation, Vol. 52, No. 4, Taylor \& Francis, Ltd., 2007, pp. 281-288.

34. Ihde, A. J.; The Development of Modern Chemistry, Herper \& Row: New York, 1964, p. 244.
35. Ref. 16, p. 72 .

36. Béguin, J.; Johannis Beguini Tyrocynium Chymicum, Genebra, 1660, p. 44.

37. Kelly, L. G.; Basil Valentine, His Triumphant Chariot of Antimony, Garland Publishing: New York, 1990.

38. Mendes, J. A.; Governo de Mineiros, mui necessário para os que vivem distantes de professores seis, oito, dez e mais léguas, padecendo por esta causa os seus domésticos e escravos queixas, que pela dilação dos remédios se fazem incuráveis, e as mais das vezes mortais (1770), organização, estudo crítico e notas por Filgueiras, C. A. L.; Arquivo Público Mineiro, Belo Horizonte, 2012.

39. Ref. 3, pp. 146-156. 